Research Article

\title{
ALTERNATIVE TO OFF-SEASON SUGAR SUPPLEMENT FEEDING OF HONEYBEES
}

\author{
K. R. Neupane and R. B. Thapa \\ Institute of Agriculture and Animal Sciences, Rampur, Chitwan, Nepal
}

\begin{abstract}
An experiment was conducted at Gorkha Bee Farm, Yagyapuri, Chitwan during rainy season of 2005 to investigate alternative to sugar supplement feeding and reduce cost feeding during off- season. Apis mellifera L. honeybee colonies were prepared with 5 frames of covering bees and 3.5 frames of broods and a queen of similar quality each of five different supplemental feedings: i) sugar syrup (1:1 sugar and water); ii) rice bran syrup (100 gm rice bran soaked in 1 lit water and after 4 hours blended, filtered and added $200 \mathrm{gm}$ sugar +20 gm honey and required water to make 1 lit); iii) maize syrup (100 gm maize flour soaked in 1 lit water and after 4 hours blended, filtered and added $200 \mathrm{gm}$ sugar $+20 \mathrm{gm}$ honey and required water to make 1 lit); iv) banana syrup (100 gm ripen peeled banana mixed in 1 lit water, blended, filtered and added $200 \mathrm{gm}$ sugar $+20 \mathrm{gm}$ honey and required water to make 1 lit); and v) pumpkin syrup (100 gm boiled pumpkin after removing outer hard core mixed in 1 lit water, blended, filtered and added $200 \mathrm{gm}$ sugar +20 gm honey and required water to make 1 lit) was placed inside the hive in a division board feeder @ 30 ml per frame of honeybees per day at an interval of 3 days. Feeding honeybees with sugar syrup increased number of brood cells by $53.5 \%$, brood frames by $37.1 \%$ and frames covered by bees by $32.0 \%$. Honeybee colonies when fed with banana and pumpkin syrup increased brood cells by $16.3 \%$ and $2.8 \%$, brood frames by $17.1 \%$ and $8.6 \%$ and bees covered number of frames by $12.0 \%$ and $3.2 \%$, respectively. Number of brood cells, brood frames and covered frames by bee remained almost constant when honeybees fed with pumpkin syrup. On the other hand, feeding bee colonies with maize and rice bran syrup decreased the number of brood cells by $11.2 \%$ and $35.2 \%$, brood frames by $11.4 \%$ and $11.4 \%$ and bees covered frames by $24.0 \%$ and $24.0 \%$, respectively. The cost of off-season feeding was the highest (Rs. 247.0) for sugar syrup followed by maize syrup (Rs. 140.4), banana syrup (Rs. 117.4), rice bran (Rs. 113.4), and pumpkin syrup (Rs.105.4). All of the feeding materials were safe to bee feeding. Banana syrup feeding was found superior to others, and therefore, its supplementation can reduce the cost of sugar feeding by more than $50 \%$ and increase brood production during off-season.
\end{abstract}

Key words: Off- season, honeybee feeding, sugar supplement

\section{INTRODUCTION}

Honeybees need several nutrients, like carbohydrates, proteins, lipids, vitamins, and minerals for their growth and development. They receive carbohydrates from nectar and proteins from pollen (Javaheri et al., 2000). Feeding bees with pollen substitute and sugar syrup increase the number of bees and frames covered by bees, brood area and colony weight much higher than feeding only sugar syrup or pollen (Sahinler, et al., 2003). Availability of natural nectar and pollen becomes scarce for honeybees during rainy season in Nepal. In some areas of the country, even if nectar and pollen are available, honeybees cannot utilize them due to the unfavorable climatic situations. Therefore, beekeepers must feed honeybees artificially during off-season. Sugar is the main commodity to feed honeybees during off-season. However, the price for sugar is increasing every year making beekeeping an expensive enterprise. Therefore, this study was carried out at Gorkha Bee Farm at Yagyapuri, Chitwan, Nepal in rainy season of 2005 to investigate the suitable and cheaper feeding material (s) to reduce the cost of feeding and keep bees viable during off-season.

\section{MATERIALS AND METHODS}

Initially, different cereals, vegetables and fruits were tested as hit and trial methods for feeding honeybees during rainy season. Out of the several materials tested, rice bran, maize white powder, ripen banana (Green varieties), and ripen pumpkin and sugar as control were selected for this study based on their availability, honeybee's feeding preference, and reasonable price. 


\section{Preparation of feeding materials and experimentation}

\section{Sugar syrup (control)}

Sugar syrup was prepared by dissolving equal volume of crystal sugar with equal volume of fresh water, i.e. 1:1.

\section{Rice bran syrup}

One hundred gram of rice bran was mixed in one liter of fresh water and kept for 4 hours. The mixture was blended properly and filtered through a muslin cloth, and one liter rice bran syrup was prepared by adding fresh water to the filtrate including 200 gm of sugar crystal and 20 gm of honey.

\section{Maize syrup}

One hundred gram of maize white powder was added to one liter of fresh water and kept for 4 hours. The mixtures was blended properly and filtered through a muslin cloth to which 200 gm of crystal sugar and 20 gm of honey mixed and prepared to one liter by adding water.

\section{Banana syrup}

Hundred gram flesh of ripen banana was added to one liter of fresh water and blended in a mixture and filtered through a muslin cloth. Then, $200 \mathrm{gm}$ crystal sugar and $20 \mathrm{gm}$ of honey was added to substrate and mixed thoroughly. The final volume of banana syrup was made one liter by adding fresh water.

\section{Pumpkin}

The ripen pumpkin was boiled in fresh water, outer hard skin and seeds removed, and 100 gm of boiled pumpkin mixed in one liter of water and blended properly, which was filtered through a muslin cloth. $200 \mathrm{gm}$ of crystal sugars and $20 \mathrm{gm}$ of honey was mixed thoroughly and final one liter pumpkin syrup was prepared by adding fresh water.

\section{Study site and design}

The study was conducted at Gorkha Bee Farm, Yagyapuri, Chitwan from August to October, 2005 when there was acute shortage of floral sources within the foraging areas. The experiment was conducted in RCBD with 5 treatments and 5 replications. The data were analyzed and means were compared with the Duncan's Multiple Range Test. Finally, the cost of different feeding materials was calculated and compared to each other to find the cheapest feed supplementation.

\section{Colony preparation and feeding}

Experimental honeybee colonies were prepared with 5 frames of covering bees and 3.5 frames of broods and a queen of similar quality. The experiment was conducted on Apis mellifera L. colonies assigning 10 colonies to each feeding treatment feeding inside the hive in a division board feeder @30 ml per frame of honeybees per day at an interval of 3 days. In addition, each experimental bee colony was given 500 gm of artificial pollen substitute for each month. The total amount of syrup given to each colony was recorded each time of feeding and syrup utilized by bees was calculated after three days of feeding by subtracting the remaining amount in the brood feeder.

\section{Data recording}

The number of brood cells (cell having egg or larva or pupa) and honey cells (cell having honey), total number of frames covered by bees, total number of brood frames (frame having brood cells) were recorded at weekly interval and the impact of different feeding materials for supplementing sugar feeding was evaluated using these parameters.

\section{RESULTS AND DISCUSSION}

\section{Feeding preference}

Honeybees preferentially collected and utilized all sugar syrup (100\%) followed by pumpkin (99.5\%), banana $(96.7 \%)$, maize powder $(90.1 \%)$ and rice bran $(59 \%)$ syrup for their nutrient requirements as indicated 
by $0.0,38.8,234.4,385.0$ and $1023.4 \mathrm{ml}$ feeds remaining out of $7230.0,7002.0,7128.0,4038.0$ and $2496.0 \mathrm{ml}$ of sugar, pumpkin, banana, maize and rice bran syrup given for feeding, respectively (Table 1). Rice bran and maize powder syrup fermented in the feeder bag after 24 hours of feeding, where as banana and pumpkin syrup started to ferment after 48 hours of feeding. Bees were drawn in banana, maize and rice bran syrup when it was too thick. However, bees were comparatively safer in pumpkin syrup feeding.

Table 1. Amount of feed supplement unutilized by honeybees during off-season (August to October, 2004)

\begin{tabular}{|llcccc|}
\hline SN & Treatments & Given amount $(\mathrm{ml})$ & Consumed amount $(\mathrm{ml})$ & Leftover amount $(\mathrm{ml})$ & Utilized amount $(\%)$ \\
\hline 1 & Sugar syrup (Control) & 7230.0 & 7230.0 & 0.0 & 100.0 \\
2 & Rice bran syrup & 2496.0 & 1472.6 & 1023.4 & 59.0 \\
3 & Maize syrup & 4038.0 & 3656.0 & 385.0 & 91.1 \\
4 & Pumpkin syrup & 7128.0 & 6893.6 & 234.4 & 96.7 \\
5 & Banana syrup & 7002.0 & 6963.2 & 38.8 & 99.5 \\
\hline
\end{tabular}

Average of five replications

\section{Effect of feeding treatments on brood and honey cells}

Brood cells were almost similar at the beginning of the experiment. The number of brood cells in the experimental bee colonies differed for different feeding materials. At the end of the off-season feeding (AugustOctober), the highest number of brood per colony was recorded in colonies fed with sugar syrup

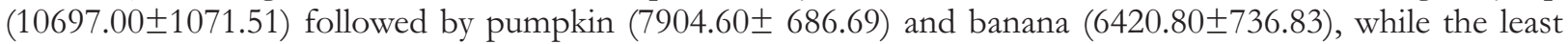

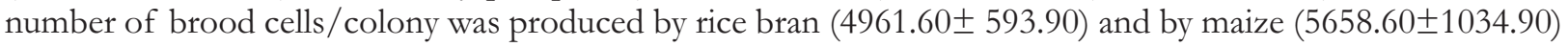
syrup feeding, respectively (Table 2).

The number of cells with honey were the highest in colonies fed with sugar syrup (4445.30 \pm 605.47$)$

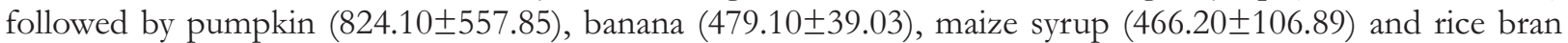
(242.24 \pm 137.96$)$ syrup, respectively. The colonies fed with sugar syrup stored the highest amount of honey and colonies fed with rice bran stored the least.

Table 2. Number of brood cells per colony at the beginning (August) and at the end (October 2004)

\begin{tabular}{|lccc|}
\hline Treatments & Brood cells No. (beginning) & Brood cells No. (at the end) & Honey cells No. \\
\hline Sugar syrup (Control) & $6968.00 \pm 421.03$ & $10697.00 \pm 1071.51$ & $4445.30 \pm 605.47$ \\
Rice bran syrup & $7661.80 \pm 792.91$ & $4961.60 \pm 593.90$ & $242.24 \pm 137.96$ \\
Maize syrup & $6370.60 \pm 523.93$ & $5658.60 \pm 1034.90$ & $466.20 \pm 106.89$ \\
Pumpkin syrup & $6796.80 \pm 1200.39$ & $7904.60 \pm 686.69$ & $824.10 \pm 557.85$ \\
Banana syrup & $6248.20 \pm 760.07$ & $6420.80 \pm 736.83$ & $479.10 \pm 39.03$ \\
\hline
\end{tabular}

Average of five replications, values after \pm indicate SE

\section{Effect of feeding treatments on brood frames and honeybees}

The trend of brood frame increasing is presented in Table 3. The total number of frames was different in sugar, banana and pumpkin syrup feeding but not between maize and rice syrup feeding treatments. Sugar syrup feeding produced the highest number of covering frames of bees (6.6) and brood frames (4.8) followed by pumpkin (5.6 and 4.1), banana (5.1 and 3.8), rice (3.8 and 3.4), and maize bran (3.8 and 3.1) in two months syrup feeding experiment, respectively (Table 3 ).

Table 3. Increased number of brood frames and brood frames covered by honeybees/experimental colony

\begin{tabular}{|c|c|c|c|c|c|c|c|c|c|c|}
\hline \multirow[b]{2}{*}{ Treatments } & \multicolumn{2}{|c|}{$1^{\text {st }}$ September } & \multicolumn{2}{|c|}{$15^{\text {th }}$ September } & \multicolumn{2}{|c|}{$30^{\text {th }}$ September } & \multicolumn{2}{|c|}{$15^{\text {th }}$ October } & \multicolumn{2}{|c|}{$30^{\text {th }}$ October } \\
\hline & $\begin{array}{l}\text { Brood } \\
\text { frames }\end{array}$ & $\begin{array}{l}\text { Frames } \\
\text { covered } \\
\text { by bees }\end{array}$ & $\begin{array}{l}\text { Brood } \\
\text { frames }\end{array}$ & $\begin{array}{l}\text { Frames } \\
\text { covered } \\
\text { by bees }\end{array}$ & $\begin{array}{l}\text { Brood } \\
\text { frames }\end{array}$ & $\begin{array}{l}\text { Frames } \\
\text { covered } \\
\text { by bees }\end{array}$ & $\begin{array}{l}\text { Brood } \\
\text { frames }\end{array}$ & $\begin{array}{l}\text { Frames } \\
\text { covered }\end{array}$ & $\begin{array}{l}\text { Brood } \\
\text { frames } \\
\text { by bees }\end{array}$ & $\begin{array}{l}\text { Frames } \\
\text { covered }\end{array}$ \\
\hline Sugar syrup (Control) & 3.0 & 5.0 & 3.1 & 5.1 & 5.1 & 5.5 & 4.8 & 6.6 & 4.8 & 6.6 \\
\hline Rice bran syrup & 3.0 & 5.0 & 3.4 & 4.5 & 3.4 & 4.1 & 3.1 & 3.8 & 3.4 & 3.8 \\
\hline Maize syrup & 3.0 & 5.0 & 2.8 & 4.0 & 3.0 & 4.0 & 3.1 & 3.8 & 3.1 & 3.8 \\
\hline Pumpkin syrup & 3.0 & 5.0 & 3.1 & 5.0 & 3.2 & 5.1 & 3.5 & 4.8 & 4.1 & 5.6 \\
\hline Banana syrup & 3.0 & 5.0 & 3.1 & 5.1 & 3.5 & 5.1 & 3.8 & 5.0 & 3.8 & 5.1 \\
\hline
\end{tabular}




\section{Cost of supplemental feeding during dearth season}

The cost of feeding for bee colonies having 10 frames of covering bees varied greatly between sugar, rice bran, maize, banana and pumpkin syrup feedings. The highest cost of feeding was recorded for sugar (Rs 247.0) followed by maize (Rs 140.4), banana (Rs 117.9), rice bran (Rs 113.4) and pumpkin (Rs 104.4) syrup, respectively. It has been found from the experiment that the cost of sugar feeding during off-season can be reduced by more than $50 \%$ by feeding bees with banana syrup (Table 5).

Table 5. Cost of feeding materials for a month @ 9 liters per 10 frame bee colony

\begin{tabular}{|c|c|c|c|c|c|}
\hline SN & Feeding materials & Required items & Unit cost (Rs) & Total cost (Rs) & Grand total (Rs) \\
\hline 1 & Sugar syrup & $6.5 \mathrm{~kg}$ & 38.0 & 247.0 & 247.0 \\
\hline \multirow[t]{3}{*}{2} & Banana syrup & 1. Banana flesh ( $900 \mathrm{gm}=15$ bananas) & $1.5 /$ banana & 22.5 & 117.9 \\
\hline & & 2. Sugar $(1.8 \mathrm{~kg})$ & $38.0 / \mathrm{kg}$ & 68.4 & \\
\hline & & 3. Honey $(180 \mathrm{Gm})$ & $150.0 / \mathrm{kg}$ & 27.0 & \\
\hline \multirow[t]{3}{*}{3} & Pumpkin syrup & 1. Pumpkin flesh (900gm) & $10.0 / \mathrm{kg}$ & 9.0 & 104.4 \\
\hline & & 2. Sugar $(1.8 \mathrm{~kg})$ & $38.0 / \mathrm{kg}$ & 68.4 & \\
\hline & & 3. Honey $(180 \mathrm{gm})$ & $150.0 / \mathrm{kg}$ & 27.0 & \\
\hline \multirow[t]{3}{*}{4} & Maize syrup & 1. Maize powder ( $900 \mathrm{gm})$ & $50.0 / \mathrm{kg}$ & 45.0 & 140.4 \\
\hline & & 2. Sugar $(1.8 \mathrm{~kg})$ & $38.0 / \mathrm{kg}$ & 68.4 & \\
\hline & & 3. Honey (180 gm) & $150.0 / \mathrm{kg}$ & 27.0 & \\
\hline \multirow[t]{3}{*}{5} & Rice bran & 1. Rice bran (900gm) & $20.0 / \mathrm{kg}$ & 18.0 & 113.4 \\
\hline & & 2. Sugar $(1.8 \mathrm{~kg})$ & $38.0 / \mathrm{kg}$ & 68.4 & \\
\hline & & 3. Honey $(180 \mathrm{gm})$ & $150.0 / \mathrm{kg}$ & 27.0 & \\
\hline
\end{tabular}

At the prevailing market price during the experimental period (August-October 2004)

\section{DISCUSSIONS}

Honeybees most preferentially collected and utilized sugar syrup followed by pumpkin and banana syrup and utilized them for their nutrient requirements. The least preference was given to rice bran and maize syrup. Honeybee colonies receiving sugar syrup collected, stored and utilized all the given syrup from the beginning to the end of experiment and produced the highest number of brood frames, brood cells and covering of frames by bees followed by the colonies fed with banana, pumpkin, maize and rice bran syrup. Honeybees fed with sugar syrup produced high number of brood cells, brood frames and number of frames covered by bees by $53.5 \%, 37.1 \%$ and $32.0 \%$, respectively. Bees when fed with banana syrup utilized $96.7 \%$ of the total given syrup and produced increased number of brood cells by $16.3 \%$, brood frames by $17.1 \%$ and covering frames of bees by $12.0 \%$, respectively. Similarly, bees when fed with pumpkin syrup utilized $99.5 \%$ of the total given syrup and produced increased number of brood cells by $2.8 \%$, brood frames by $8.6 \%$, covering of frames by bees by $3.2 \%$, respectively. However, the production of brood cells, brood frames and number of frames covered by bees declined from the initial time of the experiment by $11.2 \%, 11.4 \%$ and $24 \%$, respectively, when bees were fed with maize syrup. Similarly, honeybees when fed with rice bran syrup, utilized $59.0 \%$ of the total given syrup and produced declined number of brood cells, brood frame and covering number of frames by $35.2 \%$, $11.4 \%$ and $24 \%$, respectively.

Nutrition of honeybees involves various chemicals, such as carbohydrates, fats, proteins, minerals and vitamins. Flowers are the mainstay of the bee's life from where they collect pollen, a protein rich food and nectar, which is a major source of energy. The key indicators for the proper health and development of bees are vitamin A, B1, B2, B6, folic acid and minerals, such as iron, manganese and zinc in the pollen (Dietz, 1975; Vivino and Palmer, 1994). Fruits, vegetables and cereals rich in carbohydrates, proteins, vitamins, and minerals are easily available during off-season and are cheaper in price that can be taken as alternatives to feed bees during off-season. Banana is the cheapest and the most nutritious than any other fruits (Abdul et al., 1990). Similarly, pumpkin, rice bran and maize powder, which are easily available during off-season are also cheaper and rich in nutrition. Feeding bees with banana and pumpkin syrup provides not only energy, but also supplies protein, vitamins and minerals. Banana contains very high caloric value (2400 cal per $100 \mathrm{gm}$ fruit flesh) and tissue building elements. It contains nearly all the essential nutrients including, minerals, vitamins, (Abdul et al., 1990; Singh, 1979). Pumpkin fruit also contains protein (1.4\%), minerals $(0.69 \%)$, vitamins A, B, and C, but it has fairly less carbohydrate content (4.6\%) (Chaudhary, 1996). It has been reported that rice bran, buckwheat powder, sweet pumpkin, turnip; malus fruits are used to feed bees during off-season in the higher hills of Nepal 
(Upadhya, 2003). Hrassnigg et al. (2003) has also reported that honeybees can utilize the complex carbohydrate that underlines their important roles as food processors in the honeybee society. Therefore, feeding bees with fruits or vegetables or cereals rich in carbohydrates, proteins, minerals and fats can be the best alternative to replace expensive cane sugar.

It has been found from the experiment that the honeybee colony was viable when fed with banana syrup, which also increased the production of broods and bees, while feeding pumpkin syrup helped keeping honeybees viable during off-season. On the other hand, honeybees when fed with maize and rice bran syrup decreased the broods and bees. However, The store of honey in the experimental bee colonies fed with rice bran, maize, and pumpkin syrup was insufficient for the requirements of bees. The cells with honey in the banana feeding colonies were enough only to keep the bees viable. None of the syrup was found toxic to bees. Also, there was no incidence of any pests and diseases of bees in all the experimental bee colonies. The worker bees of none of the experimental colonies pulled and throw out the broods due to the acute shortage of food inside the hive.

\section{CONCLUSIONS}

Feeding bees with pumpkin syrup increased brood and bees as compared to banana, maize and rice bran syrup. In addition, feeding bees with pumpkin syrup reduced the cost of feeding by more than $50 \%$ than that of sugar feeding. Therefore, pumpkin and banana syrups have been found superior to rice bran, maize powder can be suggested for feeding bee colonies during off-season to reduce the cost of feeding and keep bees more viable.

\section{ACKNOWLEDGEMENTS}

The authors express their profound appreciation to the National Agriculture Research and Development Funds (NARDF) for providing research grant to conduct this research. Sincere thanks to Directorate of Research and Publications, IAAS, Rampur, Chitwan for providing administrative and logistic support to carryout this research. The authors also are grateful to Gorkha Bee Farm, Yagyapuri and their staffs for providing all necessary tools, space and other supports to complete this experiment.

\section{REFERENCES CITED}

Abdul Khader, J. B. M. MD., K. Chellappan, P.K. Chattopadhaya and O. A. A. Pillai. 1990. Banana. In: T. K. Boss and S. K. Mitra (eds.) Fruits: Tropical and Subtropical. Naya Prakashan, Calcutta, India. pp. 132-185.

Dietz, A. 1975. Nutrition of adult honeybees. In: C. P. Dadant, C. C. Dadant, M. G. Dadant and J. C. Dadant (eds.) The Hive and The Honeybee. Dadant and Sons, Inc. Hamilton, USA. pp. 125-156.

Vivino, A. E. and E. S. Palmer. 1994. The chemical composition and nutritional value of protein collected by bees. Archs Biochem. 4:129-136.

Hrassnigg, N., R. Brodschneider, P. Fleischmann, K. Crailsheim. 2003. Worker bees (Apis mellifera. L) are able to utilize starch as fuel for flight while drones are not. Final Program and Abstracts, $38^{\text {th }}$ Apimondia, Apic. Cong., Slovenia, August 24-29, 2003. pp. 642 (Abstract).

Javaheri, S. D., M. Esmaili, A. Nkkhaohi, S. A. Mirhadi and H. Tahnasebi. 2000. Honeybees with protein supplement and pollen substitute and its effects on development and resistance of honeybee's colonies and honey production. $7^{\text {th }}$ IBRA Conf. $/ 5^{\text {th }}$ AAA Conf., Changmai, Thailand. pp. 76 (Abstract).

Sahinler, N., A. Sahin and S. Kaya. 2003. The effect of supplementary feeding on honeybee (Apis mellifera) colony performance. Final Program and Abstracts, $38^{\text {th }}$ Apimondia, Apic. Cong., Slovenia, August 24-29, 2003. pp. 158 (Abstract).

Singh, S. 1979. Fruits. The National Book Trust, New Delhi, India. 213 p.

Upadhya, S. 2003. Uchha Pahadi Chhetra Ma Paramparagat Mauri Palan Prabidhi Aajako Abasekata. Nepal Mauri Journal. \# 2. Apinet, Nepal. 